Eric Studt, S.J.

Boston College

School of Theology and Ministry

\title{
Life and Death in the Body of Christ
}

This paper works with a Stoic reading of Paul's conception of pneuma - usually translated in Paul's writings as "spirit"1 —and applies this reading to Paul's exhortation concerning the Lord's supper in 1 Corinthians 11 . We will pay particular attention to how the manner of participation in Lord's supper is a matter of life and death.

Dale Martin and Troels Engberg-Pedersen, among others, have argued that Paul was operating with a Stoic conception of pneuma. That is not to say that Paul was a Stoic. ${ }^{2}$ Rather, his worldview, in particular his conception of pneuma, was partly informed by Stoic cosmology.

Following Stoic cosmology, the $1^{\text {st }}$-century Greco-Roman world saw pneuma as a material substance. ${ }^{3}$ Writers from this period commonly described pneuma as a kind of bodily

\footnotetext{
${ }^{1}$ It is unlikely that Paul was thinking in terms of the "Holy Spirit" as it was dogmatically defined by later writers and councils. See Clint Tibbs, "The Spirit (World) and the (Holy) Spirit among the Earliest Christians: 1 Corinthians 12 and 14 as a Test Case," The Catholic Biblical Quarterly 70 (2008): 317.

${ }^{2}$ Troels Engberg-Pedersen, Cosmology and Self in the Apostle Paul: The Material Spirit (New York: Oxford University Press, 2010), 6. John Levinson offers a helpful critique of EngbergPedersen's Stoic characterization of Paul in "Paul in the Stoa Poecile: A Response to Troels Engberg-Pedersen, Cosmology and Self in the Apostle Paul: The Material Spirit," Journal for the Study of the New Testament 33/4 (2011): 415-432. Levinson introduces examples that EngbergPedersen does not consider, places greater focus on Paul's Jewish heritage, and questions the selectiveness of Engberg-Pedersen's representative examples of Stoic thought.

${ }^{3}$ Dale B. Martin, The Corinthian Body (New Haven: Yale University Press, 1999), 6, 10, 13. For a critical review of Martin's theses, see Robin Scroggs, "The Corinthian Body by Dale B. Martin," The Catholic Biblical Quarterly 59/2 (1997): 384-386. I agree with Scroggs that Martin's main thesis, namely that Paul is arbitrating something like class warfare between "the Strong" (i.e., those with status) and "the Weak," is overstated. Martin's book nevertheless provides a breadth and depth of research into the $1^{\text {st }}$-century context that is useful for our current investigation.
} 
matter that flowed through the veins. ${ }^{4}$ Pneuma was considered to be the stuff that allows for life, perception, and cognition, among other things. ${ }^{5}$

Paul uses the term pneuma in various ways, of which we will consider two. The first kind of pneuma might be called "anthropological pneuma,"6 or the pneuma that is in every human being and allows for the normal functions of life, perception, and cognition. Another kind of pneuma, God's pneuma or holy pneuma, takes hold of the believer at baptism (1 Cor. $12: 13),{ }^{7}$ but, until Christ's coming, it always exists in tension with the merely anthropological pneuma in the life of the believer. Interestingly enough, the divine pneuma acts in the same way as the anthropological pneuma, except that it grants believers imperishable life as well as the perception and cognition of divine things. ${ }^{8}$

The distinction between anthropological and divine pneuma comes across in 1 Corinthians 2:9-16. Verses 9-10 state: "What no eye has seen, nor ear heard, nor the human heart conceived, what God has prepared for those who love him — these things God has revealed to us through the pneuma; for the pneuma searches everything, even the depths of God" (NRSV). This divine pneuma constitutes, in effect, new eyes, new ears, and a new heart, ones that are capable of perceiving and understanding divine realities. Verse 11 makes explicit the distinction between anthropological and divine pneuma: "For what human being knows what is truly human

\footnotetext{
${ }^{4}$ Martin, 13.

${ }^{5}$ Ibid., 22.

${ }^{6}$ Engberg-Pedersen, 18. The term "anthropological pneuma" comes from Friedrich Wilhelm Horn. My use of the term, however, does not follow Horn's description exactly. I use the phrase in order to differentiate the kind of pneuma that is in every human being from the divine pneuma that only exists in believers.

${ }^{7}$ Ibid., 194-195, 197. Engberg-Pedersen explains that the story is bit more complicated. In order for Paul's account to make sense, it would be necessary for believers to receive some portion of God's pneuma before baptism, probably through the preaching of an apostle. He offers the following model: "(initial) pneuma/pistis $\rightarrow$ baptism $\rightarrow$ (full) pneuma $\rightarrow$ sonship." ${ }^{8}$ Ibid., 62-63. Engberg-Pedersen calls this the "instrumental function" of pneuma.
} 
except the human pneuma that is within? So also, no one comprehends what is truly God's except the pneuma of God." The pericope continues by explaining that only those with God's pneuma can understand divine realities; to the merely human pneuma, divine realities seem like foolishness (12-15). The pericope ends with a rhetorical flourish. Quoting Isaiah, Paul asks: "For who has known the mind of the Lord so as to instruct him?" The response: "But we have the mind of Christ" (16). According to the Stoic cosmology, pneuma (spirit) and nous (mind) are two words for the same reality. ${ }^{9}$ The same pneuma that exists in Christ, then, animates believers and gives them access to the divine mind. This last point is essential: believers have a sharing with the risen Christ in the one divine pneuma. ${ }^{10}$

In 1 Corinthians Paul describes two kinds of pneumatic bodies of believers and both examples point to the same reality. In 3:16-17 Paul talks about the community of believers as "God's temple" in which God's pneuma dwells. Here the temple metaphor is meant to address the factionalism in the community; some identify themselves with Apollos, some with Paul, some with Cephas (22). Paul is explaining that the Corinthian community forms a single unit in which God's pneuma dwells. We will call this first kind of pneumatic body "the corporate pneumatic body." In 6:20 the same metaphor is used to describe the body of the individual believer: "Or do you not know that your body is a temple of the holy pneuma within you, which you have from God, and that you are not your own?" Here the temple metaphor addresses what we usually think of as personal transgressions such as fornication, idolatry, adultery, prostitution, etc. (9-10). We will call this second kind of pneumatic body the "individual pneumatic body of

\footnotetext{
${ }^{9}$ Ibid., 63.

${ }^{10}$ Ibid., 56. As Engberg-Pedersen explains, the total identification of the believer with Christ will only be complete at Christ's coming: "[T]he body of human beings that will possess the same shape as Christ's glorious body is the physical, pneumatic resurrection body of the type mentioned in 1 Cor. 15:44. Thus the resurrected Christ will himself be a physical, pneumatic body."
} 
the believer." Paul's point, however, is that these seemingly personal transgressions are in fact attacks on the community, as he states shortly thereafter in verse 15: "Do you not know that your bodies are members of Christ? Should I therefore take the members of Christ and makes them members of a prostitute?" Activities such as fornication, idolatry, and prostitution, therefore, not only contaminate the individual transgressor's pneuma; more importantly, they pollute the divine pneuma present in the entire community, the entire body of Christ. ${ }^{11}$

The connection between the two kinds of pneumatic bodies becomes clearer in 12:12-27. Here are verses 26-27: "If one member suffers, all suffer together with it; if one member is honored, all rejoice together with it. Now you are the body of Christ and individually members of it." If we are to take the Stoic reading of Paul's use of pneuma seriously, we see that "the body of Christ" is not a metaphor in Paul, but a physical entity. Since pneuma is a bodily substance, the body of Christ is likewise a real body made up of a single substance. ${ }^{12}$ For this reason, transgressions against the divine pneuma, whether personal or communal, cause harm to the entire body of Christ.

The theme of life and death in 1 Corinthians is most vividly laid out in the apocalyptic verses in chapter 15. We will focus our attention on how Paul describes the transformation that the body will undergo at Christ's coming. Paul's contrasts two kinds of bodies in 15:45: “"The first man, Adam, became a living being'; the last Adam [i.e., Christ] became a life-giving

\footnotetext{
${ }^{11}$ Martin, 169. In this context, Martin's point refers to 5:1-5, but his remarks suit Paul's meaning in the pericope mentioned above equally well: "Paul's primary worry is that the pneuma of Christ's body will become polluted by the corrupting presence of the sinful sarx represented by the body of the immoral man." Martin's take on Paul's view in 1 Corinthians on the pollution from the outside world has come into question. See David Horrell, "The Corinthian Body. By Dale B. Martin," The Journal of Theological Studies 47/2 (1996): 628. In short, Horrell does not disagree with Martin that pollution does play a role; rather, it is the nature and extent of that pollution that Horrell questions.

${ }^{12}$ Engberg-Pedersen, 171.
} 
pneuma." $"$ The first Adam is representative of the human being without God's pneuma. A few verses later, Paul explains why the distinction between the two kinds of bodies is important: "Just as we have borne the image of the man of dust, we will also bear the image of the man of heaven" (49). The pericope continues with: "For the trumpet will sound, and the dead will be raised imperishable, and we will all be changed" (52). The transformation will be from perishability to imperishability, from mortality to immortality. The triumph of the pneumatic, heavenly Adam over the fleshly Adam is the triumph of life over death, the triumph of the divine pneuma over the anthropological pneuma of the flesh. It is not the triumph of pneuma over body, but of one kind of body over another (53). ${ }^{14}$

The above discussion serves as a necessary backdrop for understanding the pericope dealing with the Lord's supper in chapter 11. The occasion for Paul's descriptions of the Lord's supper is that the factions in the community were surfacing during the ritual celebration. $\mathrm{He}$

${ }^{13}$ For a summary of recent investigations on the origins of Paul's Adam-Christ typology, see: Stephen Hultgren, "The Origin of Paul's Doctrine of the Two Adams in 1 Corinthians 15:45-49," Journal for the Study of the New Testament 25.3 (2003): 343-370. Hultgren's thesis is that the closest parallels for Paul's first and last Adam are found in Palestinian exegetical traditions. It was Paul's encounter with the risen Christ that led Paul to associate Christ with the last Adam. ${ }^{14}$ Engberg-Pedersen, 32. "Thus Paul had the idea that 'this' individual body of flesh and blood, this 'clay' body made out of earth, will be transformed so that what is self-identically the very same body will become a body made up of pneuma. It is not that the flesh and blood will in some sense be 'shed' in such a way that it is only what remains that will be resurrected. No, the individual body of flesh and blood will be transformed as a whole so as to become through and through a pneumatic one." John M.G. Barclay critiques Engberg-Pedersen's account of the resurrection of the body in John M.G. Barclay, "Stoic Physics and the Christ-event: A review of Troels Engberg-Pedersen, Cosmology and Self in the Apostle Paul: The Material Spirit," Journal for the Study of the New Testament 33/4 (2011): 406-414. Barclay's argument, namely that Engberg-Pedersen's view of the resurrection does not capture the radicalness of Paul vision (411-412), does not reflect a careful reading of the author's claims concerning the resurrection: "The moment one thinks of the question in the simple and straightforward cosmological terms we have now seen to be Paul's, one sees that what he wanted to talk about was the generation of an altogether new pneumatic world of eternal life in which everything that was tied to the lower elements of the present world of corruption and death would be transformed into a wholly different kind of heavenly existence, indeed, into an altogether different world." (EngbergPedersen, 38). 
writes in verses 20-21: "When you come together, it is not really to eat the Lord's supper. For when the time comes to eat, each of you goes ahead with your own supper, and one goes hungry and another becomes drunk." Whatever the cause of these factions, ${ }^{15}$ it is at least clear that the practice in the community is at odds with the unity that is supposed to exist among the members of the corporate pneumatic body of Christ. Indeed, we know that Paul expected the Lord's supper to be a profound demonstration of the unity of the community, since he states in 10:1617: "The cup of blessing that we bless, is it not a sharing in the blood of Christ? The bread that we break, is it not a sharing in the body of Christ? Because there is one bread, we who are many are one body for we all partake of the one bread." 16

In chapter 11, after recounting what happened at Jesus' last supper, Paul explains that the manner of participation in the Lord's supper is a matter of life and death: "Whoever, therefore, eats the bread or drinks the cup of the Lord in an unworthy manner will be answerable for the body and blood of the Lord" (11:27), meaning that those who participate unworthily in the ritual

\footnotetext{
${ }^{15}$ It is unclear what form the factionalism takes in the present context. On the surface it seems as though it is simply a division between richer and poorer members. Drawing on research into Greco-Roman associations, Kloppenborg argues that the portion of food given to members may also reflect a jockeying for position among the members of the group. See John S. Kloppenborg, "Precedence at the Communal Meal in Corinth," Novum Testamentum 58 (2016): 167-203.

Lampe, on the other hand, argues that the Corinthians were simply following the custom of the Greco-Roman meal, which was divided into First and Second Tables, a custom that the Corinthians would have known from their secular lives. See Peter Lampe, "The Eucharist: Identifying with Christ on the Cross," Interpretation: A Journal of Bible and Theology 48 (1994): 40.

${ }^{16}$ Joseph A. Fitzmyer, First Corinthians AYB 32 (New Haven: Yale University Press, 2008), 391-392: "“The effect of koinonia in the one eucharistic body of Christ is that "we share'(metechomen) with one another in that one loaf, which brings about a unity of all Christians with the risen Lord, in 'one body'[...]" See also, Martin, 190: "Paul clearly believes that something 'real' happens to the body of the Christian through partaking in the Eucharistic meal. It is anachronistic to attribute to Paul the notion that the Eucharist had a 'merely' metaphorical or, in the modern sense of the term, 'spiritual' effect on the Christian."
} 
will be held responsible for the death of Christ. ${ }^{17}$ In the context of this pericope, unworthy participation almost certainly refers to the sin of factionalism.

Factionalism wreaks havoc on any corporate body. When we consider that Paul saw the bond linking each member of the body of Christ as physical, then factionalism becomes a literal dismemberment of the physical body of Christ. The Corinthians, then, as they ritually partake in the one body of the Lord, are at the same time tearing the body of the Lord to pieces.

For Paul, factionalism results not only in the death of the corporate pneumatic body of the community, but also in physical ailments and death for the individual believer. He writes: "For all who eat and drink without discerning the body, eat and drink judgment against themselves. For this reason many of you are weak and ill, and some have died" (11:29-30). ${ }^{18}$ Dale Martin uses the ancient concept of a pharmakon to explain Paul's meaning in this passage. ${ }^{19}$ A pharmakon was considered a substance that could act either as a medicine to promote health or as a poison to bring sickness or death. Pharmakon is a word that Ignatius of Antioch used to describe the Eucharist in his Epistle to the Ephesians, calling it the "pharmakon [or medicine] of immortality." ${ }^{20}$ Paul, in effect, is saying that the reverse is true; namely, the unworthy

\footnotetext{
${ }^{17}$ Fitzmyer, 445.

${ }^{18}$ Martin, 196-197: "By promoting the dissolution of Christ's body (the church), the Strong at Corinth render their own bodies vulnerable to the pharmakon of Christ's body (the bread). Their schismatic actions alienate them from the true body of Christ by tearing apart that body. The body of Christ that they consume is now an alien agent that brings disease and death rather than health and salvation to their own bodies."

${ }^{19}$ Ibid., 193.

${ }^{20}$ Ignatius of Antioch, "Letter to the Ephesians," Chapter 20. See also Martin, 191: "The bodily ingestion of idol-meat could mean the dangerous ingestion of the daimonic realm; the parallel with the Eucharist is simply assumed by Paul: normally it would constitute the ingestion of the body of Christ, which would of course be positive, even soteriological."
} 
participation in the Lord's supper acts as a toxin that brings sickness and death. As Martin puts it, "some of the Corinthians are eating themselves to death."21

Our Stoic reading of Paul's conception of pneuma as it applies to 1 Corinthians 11 yields an important insight: For Paul, the unity of the believing community was a matter of life and death. Those who promote factionalism literally dismember the physical body of Christ and will be subject to judgment and condemnation, perhaps including physical sickness and death. Unity in God's pneuma, on the other hand, is the promise of life.

${ }^{21}$ Martin, 194. 


\section{Bibliography}

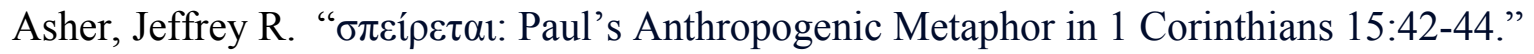
Journal of Biblical Literature 120/1 (2001): 101-122

Barclay, John M.G. "Stoic Physics and the Christ-event: A review of Troels Engberg-Pedersen, Cosmology and Self in the Apostle Paul: The Material Spirit." Journal for the Study of the New Testament 33/4 (2011): 406-414.

Bonneau, Normand. "The Logic of Paul's Argument on the Resurrection Body in 1 Cor 15:3544." Science et Esprit XLV/1 (1993): 79-92.

Fitzmyer, Jospeh A. First Corinthians: A New Translation with Introduction and Commentary. New Haven: Yale University Press, 2008.

Henderson, Suzanne Watts. “'If Anyone Hungers...': An integrated Reading of 1 Cor 11.1734.” New Testament Studies 48 (2002): 195-208.

Horrell, David. "The Corinthian Body. By Dale B. Martin.” The Journal of Theological Studies 47/2 (1996): 624-629.

Hultgren, Stephen. "The Origin of Paul's Doctrine of the Two Adams in 1 Corinthians 15:4549.” Journal for the Study of the New Testament 25.3 (2003): 343-370.

Hurtado, Larry W. Lord Jesus Christ: Devotion to Jesus in Earliest Christianity. Grand Rapids, MI: Eerdmans Publishing Co, 2003. Kindle Edition.

Kloppenborg, John S. "Precedence at the Communal Meal in Corinth." Novum Testamentum 58 (2016): 167-203

Lampe, Peter. "The Eucharist: Identifying with Christ on the Cross.” Interpretation 48 (1994): $36-49$.

Levinson, John R. "Paul in the Stoa Poecile: A Response to Troels Engberg-Pedersen, 
Cosmology and Self in the Apostle Paul: The Material Spirit." Journal for the Study of the New Testament 33/4 (2011): 415-432.

Martin, Dale B. The Corinthian Body. New Haven: Yale University Press, 1999.

Perkins, Pheme. First Corinthians. Grand Rapids, MI: Baker Publishing Group, 2012.

Scroggs, Robin. "The Corinthian Body by Dale B. Martin.” The Catholic Biblical Quarterly 59/2 (1997): 384-386.

Tibbs, Clint. "The Spirit (World) and the (Holy) Spirit among the Earliest Christians: 1 Corinthians 12 and 14 as a Test Case.” The Catholic Biblical Quarterly 70 (2008): 313330.

Engberg-Pedersen, Troels. Cosmology and Self in the Apostle Paul: The Material Spirit. New York: Oxford University Press, 2010. 